\title{
Glossopharyngeal nerve contrast enhancement in recent-onset glossopharyngeal neuralgia
}

Figure $\quad$ MRI findings in a patient with recent-onset glossopharyngeal neuralgia

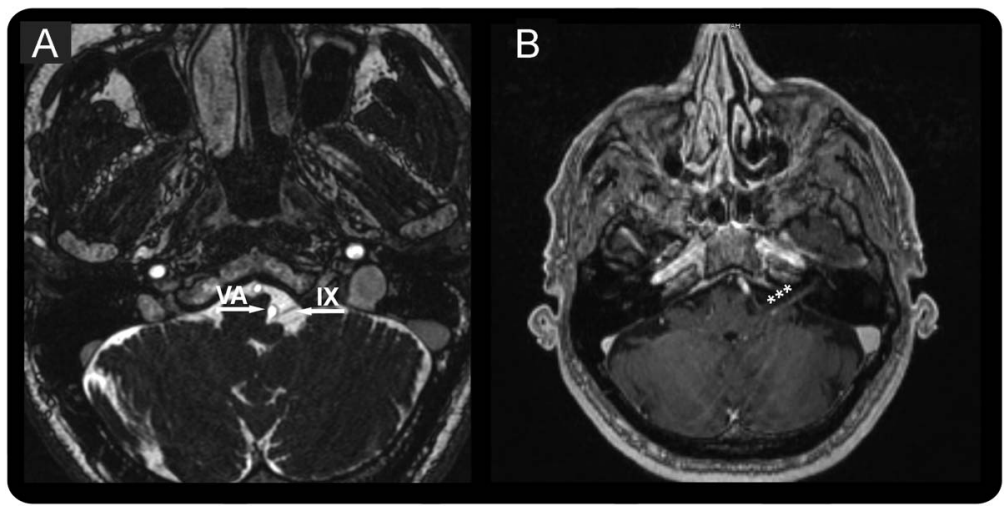

(A) T2-weighted and (B) T1-weighted contrast-enhanced images of the neurovascular conflict between the left glossopharyngeal nerve (IX) and the vertebral artery (VA). The VA, lying on the medulla, compressed the proximal portion of the glossopharyngeal nerve. The nerve showed a homogeneous enhancement $\left(^{* * *}\right)$ after gadolinium.

A 65-year-old man presented with a 2-month history of paroxysmal, stabbing pain at the base of the tongue and the left tonsillar fossa, triggered by swallowing and yawning. The remaining clinical and neurologic examinations were unremarkable. We diagnosed glossopharyngeal neuralgia and prescribed oxcarbazepine $300 \mathrm{mg}$ 3 times a day that consistently relieved pain. ${ }^{1}$ Cerebral MRI showed juxtaposition of the left glossopharyngeal nerve and the vertebral artery, with abnormal glossopharyngeal nerve contrast enhancement (figure). The abnormal glossopharyngeal nerve contrast enhancement suggests inflammatory changes, possibly induced by irritation secondary to arterial pulsations on the nerve.

Andrea Truini, MD, Claudio Colonnese, MD, Mario Manfredi, $M D$

From the Department of Neurology and Psychiatry, University Sapienza, Rome, Italy.

Author contributions: Dr. A. Truini: drafting the manuscript. Dr. C. Colonnese: acquisition and interpretation of MRI scans. Dr. M. Manfredi: critical revision of the manuscript for important intellectual content.

Study funding: No targeted funding reported.

Disclosure: The authors report no disclosures relevant to the manuscript. Go to Neurology.org for full disclosures.

Correspondence to Dr. Manfredi: mario.manfredi@uniroma1.it

1. Luef G, Poewe W. Oxcarbazepine in glossopharyngeal neuralgia: clinical response and effect on serum lipids. Neurology 2004; 63:2447-2448 


\section{Neurology}

\section{Glossopharyngeal nerve contrast enhancement in recent-onset glossopharyngeal neuralgia \\ Andrea Truini, Claudio Colonnese and Mario Manfredi \\ Neurology 2015;84;1283 \\ DOI 10.1212/WNL.0000000000001392}

\section{This information is current as of March 23, 2015}

\section{Updated Information \& Services}

References

Citations

Subspecialty Collections

Permissions \& Licensing

Reprints including high resolution figures, can be found at: http://n.neurology.org/content/84/12/1283.full

This article cites 1 articles, 1 of which you can access for free at: http://n.neurology.org/content/84/12/1283.full\#ref-list-1

This article has been cited by 1 HighWire-hosted articles: http://n.neurology.org/content/84/12/1283.full\#\#otherarticles

This article, along with others on similar topics, appears in the following collection(s):

\section{All Pain}

http://n.neurology.org/cgi/collection/all_pain

Neuropathic pain

http://n.neurology.org/cgi/collection/neuropathic_pain

Information about reproducing this article in parts (figures,tables) or in its entirety can be found online at:

http://www.neurology.org/about/about_the_journal\#permissions

Information about ordering reprints can be found online:

http://n.neurology.org/subscribers/advertise

Neurology ${ }^{\circledR}$ is the official journal of the American Academy of Neurology. Published continuously since 1951, it is now a weekly with 48 issues per year. Copyright @ 2015 American Academy of Neurology. All rights reserved. Print ISSN: 0028-3878. Online ISSN: 1526-632X.

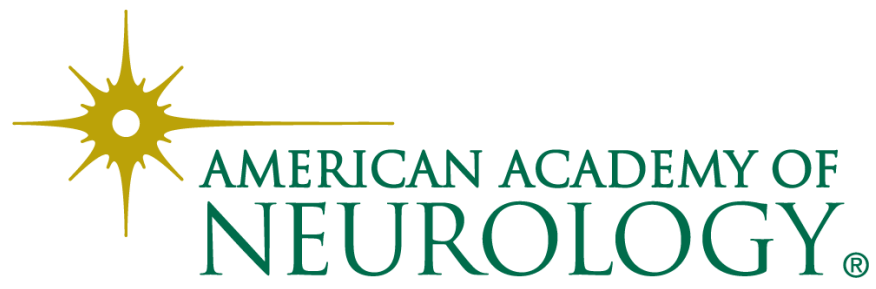

